\title{
MENINGKATKAN KEMAMPUAN GURU DALAM MELAKSANAKAN PROSES bELAJAR MENGAJAR MELALUI SUPERVISI KELOMPOK
}

\author{
Subandiyo \\ UPTD TK, SD, dan PLS Dinas Pendidikan Dau \\ Jl. Raya Mulyoagung Nomor 99 Dau Malang \\ e-mail: subandiyo1@gmail.com
}

\begin{abstract}
The purpose of this research is to improve the ability of teachers to implement PBM through supervision group. The design of this study a qualitative research approach Action Research School. The results showed that the level of ability to carry out teaching and learning activities teachers Class V increased significantly, in the first cycle obtain the value 72.10 (qualifying well), the second cycle obtain the value of 80 (good qualification) and the third cycle the average value of 86, 50 (excellent qualifications). Based on the results of this study concluded that the ability of teachers to carry out teaching and learning activities through supervision groups to increase in value. Based on the conclusions presented suggestions for teachers to continuously improve their ability with the guidance of the school supervisor/ principal and learn independently.
\end{abstract}

\begin{abstract}
Abstrak: Tujuan penelitian ini adalah untuk meningkatkan kemampuan guru melaksanakan PBM melalui supervisi kelompok. Rancangan penelitian ini penelitian kualitatif dengan pendekatan Penelitian Tindakan Sekolah. Hasil penelitian menunjukkan bahwa nilai tingkat kemampuan melaksanakan PBM para guru Kelas V meningkat secara sinifikan, pada Siklus I memperoleh nilai 72,10 (kualifikasi baik), Siklus II memperoleh nilai 80 (kualifikasi baik), dan Siklus III nilai rata-rata 86,50 (kualifikasi sangat baik). Berdasarkan hasil penelitian dapat disimpulkan bahwa kemampuan guru dalam melaksanakan PBM melalui supervisi kelompok meningkat nilainya. Berdasarkan simpulan dikemukakan saran bagi guru untuk terus meningkatkan kemampuannya dengan bimbingan dari pengawas sekolah/kepala sekolah maupun belajar secara mandiri.
\end{abstract}

Kata kunci: kemampuan guru, proses belajar mengajar, supervisi kelompok

Diterbitkannya Undang-undang Nomor 20 Tahun 2003 tentang Sistem Pendidikan Nasional dan Undang-undang Nomor 14 Tahun 2005 tentang Guru dan Dosen, merupakan upaya pemerintah untuk meningkatkan mutu pendidikan melalui peningkatan kualitas guru, karena guru merupakan salah satu komponen pendidikan yang sangat sentral dan dominan dalam pembelajaran serta menjadi komponen utama untuk peningkatan mutu pendidikan. Suparno (2008:1) mengemukakan bahwa mutu pendidikan Indonesia bukan hanya ditentukan dari pemerintah pusat, tetapi terlebih pada para guru dan dosen serta administrator lapangan yang mau selalu mengadakan refleksi, evaluasi tentang apa yang mereka lakukan dan mengadakan perubahan demi kemajuan praktik pendidikan.
Proses pembelajaran adalah merupakan suatu sistem. Pencapaian standar proses untuk meningkatkan kualitas pendidikan (proses pembelajaran) dapat dimulai dari menganalisis setiap komponen yang dapat mempengaruhi proses pembelajaran. Sanjaya (2008:13) menyatakan komponen yang selama ini dianggap sangat mempengaruhi proses pendidikan adalah komponen guru. Guru yang professional dan efektif merupakan kunci keberhasilan proses belajar mengajar. Oleh karena itu, guru adalah pekerjaan professional yang membutuhkan kemampuan khusus hasil proses pendidikan yang dilaksanakan oleh lembaga pendidikan keguruan. Cooper (1990:26) menyatakan a professional is a person who possesses ssome specialized knowledge and skills, can weigh alternatives 
and select from among a number of potentially produvtive actions one that is particularly appropriate in a given situation.

Upaya meningkatkan kualitas guru dengan demikian harus tetap dilakukan terus menerus berdasar selain Undang-undang Nomor 14 Tahun 2005 tentang Guru dan Dosen dan Peraturan Pemerintah Nomor 19 Tahun 2005 tentang Standar Nasional Pendidikan, juga Permendiknas Nomor 10 Tahun 2009 tentang Sertifikasi bagi Guru dalam Jabatan. Guru dalam proses pembelajaran di sekolah, terutama sekolah dasar, merupakan sumber daya edukatif sekaligus aktor proses pembelajaran yang utama (Marno dan Idris, 2008:16). Oleh karena itu, dalam melaksanakan proses pembelajaran kemampuan guru dalam PBM sangat menentukan kualitas proses belajar-mengajar.

Guru yang yang efektif adalah yang dapat menunaikan tugas dan fungsinya secara profesional. Untuk dapat melaksanakan tugas secara professional, diperlukan berbagai persyaratan, seperti kompetensi akademik, kompetensi metodologis, kematangan pribadi, sikap penuh dedikasi, kesejahteraan yang memadai, pengembangan karier, budaya kerja, dan suasana kerja yang kondusif. Di samping guru secara profesional harus mempunyai persyaratan tersebut di atas, tidak kalah pentingnya adalah dalam melaksanakan proses belajar mengajar perlu bantuan dari Kepala Sekolah maupun Pengawas Sekolah dalam rangka menunjang tugas-tugas guru di sekolah, terutama dalam mengelola proses belajar mengajar.

Kompetensi pengawas sekolah/madrasah yang tersirat dan tersurat dalam Permendiknas Nomor 12 Tahun 2007 tentang Standar Pengawas Sekolah / Madrasah terdiri atas enam dimensi kompetensi yang dikembangkan menjadi 36 kompetensi inti. Enam kompetensi tersebut adalah: (1) kompetensi kepribadian; (2) kompetensi sosial; (3) kompetensi supervisi manajerial; (4) kompetensi supervisi akademik; (5) kompetensi evaluasi pendidikan; dan (6) kompetensi penelitian dan pengembangan. Dalam kaitannya dengan pembinaan terhadap para guru, bidang ini adalah salah satu bidang yang termasuk dalam salah satu kompetensi pengawas sekolah yaitu supervisi. Glickman menyatakan supervisi merupakan suatu proses yang bersifat mengembangkan dalam hal ini adalah mengembangkan komptensi pribadi dan kompetensi profesional guru (Fathurrohman dan Suryana, 2011:41).

Kompetensi supervisi akademik intinya adalah membina guru dalam meningkatkan mutu proses pembelajaran. Oleh sebab itu, sasaran supervisi akademik adalah guru dalam proses belajar mengajar (pembelajaran). Materi pokok dalam proses pembelajaran adalah (penyusunan silabus dan RPP, pemilihan strategi, metode, teknik pembelajaran, penggunaan media dan teknologi informasi dalam pembelajaran, menilai proses dan hasil pembelajaran serta penelitian tindakan kelas). Dalam kaitannya dengan pembinaan terhadap para guru, terdapat program yang melaksanakan pembinaan terhadap para guru yaitu memantau dan membimbing guru dalam melaksanakan PBM.

Sementara itu dalam kenyataan di lapangan, para guru sekolah dasar yang termasuk dalam kelompok Gugus Sekolah VI dan Gugus Sekolah IX di Wilayah Kecamatan Lawang Kabupaten Malang, masih banyak guru yang belum menunjukkan kemampuan yang maksimal dalam melaksanakan PBM. Banyak faktor yang mempengaruhi para guru tersebut, terutama kurangnya pendidikan dan pelatihan yang dapat meningkatkan kualitas pengelolaan proses belajar mengajar serta belum kontinunya pembinaan dari yang berwenang membina, seperti kepala sekolah dan pengawas sekolah.

\section{METODE}

Pendekatan dalam penelitian ini merupakan pendekatan penelitian tindakan sekolah (PTS). Suhardjono (2008:10) menyatakan penelitian tindakan banyak dilakukan baik oleh guru maupun pengawas. Apabila dilakukan guru umum disebut sebagai Penelitian Tindakan Kelas (PTK). Sedangkan apabila dilakukan oleh pengawas sekolah, disebut sebagai Penelitian Tindakan Sekolah (PTS). PTS dalam konteks kependidikan mengandung pengertian PTS bentuk kegiatan refleksi diri yang dilakukan oleh para pelaku pendidikan dalam situasi kependidikan untuk memperbaiki rasionalitas dan keadilan tentang: (1) praktik kependidikan mereka; (2) pemahaman mereka tentang praktik tersebut; dan (3) situasi di mana praktik tersebut dilaksanakan (Lestari, 2008:8). 
Jenis penelitian ini merupakan penelitian tindakan sekolah, karena dari analisis dan refleksi setiap akhir kegiatan dilakukan tindakan yang berdasarkan hasil analaisis dan refleksi yang dibuat sebelumnya. Ciri penelitian tindakan kelas ini adalah digunakannya prosedur kerja siklus dalam suatu penelitian yang terdiri dari 4 tahap, yaitu perencanaan, tindakan, observasi, dan refleksi. Lokasi penelitian ini adalah SD Negeri dan Swasta di Kecamatan Lawang Kabupaten Malang, khususnya sekolah dasar negeri maupun swasta yang termasuk dalam kelompok Gugus Sekolah VI dan Gugus Sekolah IX. Rekapitulasi sekolah dasar-sekolah dasar tersebut adalah sebagai dipaparkan pada Tabel 1 .

Tabel 1 Sekolah Dasar di Wilayah Gugus Sekolah VI dan Gugus IX

\begin{tabular}{|c|c|c|}
\hline No & $\begin{array}{c}\text { Nama } \\
\text { Sekolah Dasar }\end{array}$ & Keterangan \\
\hline 1 & SDN Kalirejo 01 & Gugus Sekolah VI \\
\hline 2 & SDN Kalirejo 02 & Gugus Sekolah VI \\
\hline 3 & SDN Kalirejo 03 & Gugus Sekolah VI \\
\hline 4 & SDN Kalirejo 05 & Gugus Sekolah VI \\
\hline 5 & SDN Lawang 04 & Gugus Sekolah IX \\
\hline 6 & SDN Lawang 06 & Gugus Sekolah IX \\
\hline 7 & SDN Lawang 07 & Gugus Sekolah IX \\
\hline 8 & $\begin{array}{l}\text { SDK ST } \\
\text { Fransiskus }\end{array}$ & Gugus Sekolah IX \\
\hline 9 & $\begin{array}{l}\text { SD Mutiara } \\
\text { Harapan }\end{array}$ & Gugus Sekolah IX \\
\hline 10 & SDK Pelita Kasih & Gugus Sekolah IX \\
\hline
\end{tabular}

Pada penelitian ini peneliti bertindak sebagai instrumen kunci sekaligus pengumpul data. Oleh karena itu, kehadiran peneliti di lapangan mutlak diperlukan. Penelitian bertindak sebagai pengamat pengajaran, pelaksana pengumpulan data, penganalisis, penafsir data, pelapor hasil penelitian. Jadi pada penelitian ini peneliti bertindak sebagai pengamat penuh. Keterlibatan pihak lain hanya bersifat konsultatif dalam mempertajam persoalan-persoalan pembelajaran yang dihadapi guru sekiranya layak untuk diuraikan melalui penelitian tindakan sekolah. Selain instrumen kunci juga digunakan instrumen lain yaitu dokumentasi.

Pada penelitian ini peneliti berperan sebagai pengamat sekaligus pelaksana tindakan, dimana peneliti berperan sebagai guru yang menerapkan pendekatan observasi (pengamatan) terhadap kemampuan guru dalam proses belajar mengajar (PBM). Data yang akan diambil dalam penelitian ini adalah data tentang kemampuan guru Kelas $\mathrm{V}$ dalam melaksanakan PBM dalam kelompok Gugus Sekolah VI dan VI di wilayah Kecamatan Lawang Kabupaten Malang yang seluruhnya ada 10 sekolah dasar, baik negeri maupun swasta sebagaimana yang telah dipaparkan pada Tabel 1.

Data tentang kemampuan guru dalam melaksanakan PBM diambil dari sumber primer yang merupakan data empiris berupa performansi guru di kelas yang berkaitan dengan pelaksanaan PBM selama proses belajar mengajar, yaitu dengan menggunakan Instrumen Penilaian Pelaksanaan Pembelajaran (IPPP). Sumber data sekunder adalah data yang diperoleh melalui perantara atau pihak lain. Selain itu data sekunder dalam penelitian ini adalah daftar sekolah dasar baik negeri maupun swasta dalam Kelompok Gugus Sekolah VI dan Gugus Sekolah IX serta nama-nama guru Kelas $\mathrm{V}$ yang menjadi responden dalam penelitian tindakan sekolah ini di wilayah Kecamatan Lawang Kabupaten Malang.

Teknik pengumpulan data yang digunakan dalam penelitian tindakan sekolah ini adalah observasi dan catatan lapangan. Analisa data yang dikumpulkan dalam penelitian ini, yaitu data kuantitatif dan data kualitatif. Data kuantitatif berupa hasil observasi pelaksanaan PBM. Data kualitatif berupa hasil catatan lapangan. Prosedur kerja dalam penelitian tindakan ini dilaksanakan dalam tiga siklus kegiatan yaitu siklus I, II dan III. Masing-masing siklus terdiri dari empat tahap kegiatan, yaitu: (1) menyusun rencana tindakan; (2) melaksanakan tindakan; (3) melakukan observasi; dan (4) membuat analisis dilanjutkan dengan refleksi.

\section{HASIL}

\section{Hasil Penelitian}

\section{Siklus 1}

\section{Perencanaan}

Peneliti dalam pelaksanaan siklus I melakukan pengamatan langsung kepada para guru yang telah dijadikan responden. Sebelum melaksanakan proses pembelajaran, hal-hal yang 
disiapkan dalam pemberian tindakan I adalah: (1) guru menyiapkan rencana pembelajaran yang akan dilaksanakan dalam PBM; (2) peneliti menyiapkan instrumen PPP untuk merekam hasil pengamatan selama guru melaksanakan PBM; (3) menyusun pedoman wawancara untuk wawancara pada akhir siklus; dan (4) indikator yang dinilai dalam Instrumen PPP mencakup halhal seperti yang disajikan Tabel 2 .

\section{Pelaksanaan}

Prosedur pembelajaran yang dilaksanakan sesuai dengan scenario yang direncanakan. Setelah tanda bel masuk berbunyi, guru di depan kelas dan mengucapkan salam serta menyuruh ketua kelas untuk memimpin doa. Menciptakan kondisi awal pembelajaran dengan cara mengecek kehadiran guru, menciptakan kesiapan belajar guru, dan menciptakan suasana belajar yang demokrasi. Melaksanakan apersepsi dengan cara mengajukan pertanyaan-pertanyaan. Memberi komentar terhadap jawaban guru serta membangkitkan motivasi dan perhatian guru. Setelah itu menghubungkan materi pembelajaran yang telah dimiliki guru dengan materi yang akan dibahas.

Memberitahukan judul materi dan tujuan pembelajaran yang akan dipelajari serta ditulis di papan tulis. Peneliti menyampaikan kegiatan belajar yang ditempuh guru. Menyajikan materi pelajaran secara klasikal dengan ceramah bervariasi. Guru menjawab pertanyaanpertanyaan yang diajukan dan bertanya tentang hal-hal yang belum dimengerti. Guru tidak terusmenerus menjelaskan tetapi selang beberapa menit selain memberi kesempatan kepada guru untuk bertanya, kemudian dilanjutkan dengan

Tabel 2 Indikator yang Dinilai dalam Instrumen PPP

\begin{tabular}{|c|c|}
\hline No & Indikator/Aspek yang Dinilai \\
\hline 1 & Mempersiapkan semua siswa untuk belajar \\
\hline 2 & Melakukan kegiatan apersepsi \\
\hline 3 & Menunjukkan penguasaan materi pelajaran \\
\hline 4 & Mengaitkan materi dengan pengetahuan lain yang relevan \\
\hline 5 & Menyampaikan materi dengan jelas, sesuai dengan hirarki belajar dan karakteristik siswa \\
\hline 6 & Mengaitkan materi dengan realitas kehidupan \\
\hline 7 & $\begin{array}{l}\text { Melaksanakan pembelajaran sesuai dengan kompetensi (tujuan) yang akan dicapai dan karakteristik } \\
\text { siswa. }\end{array}$ \\
\hline 8 & Melaksanakan pembelajaran secara runtut \\
\hline 9 & Menguasai kelas \\
\hline 10 & Melaksanakan pembelajaran yang bersifat kontekstual \\
\hline 11 & Melaksanakan pembelajaran yang memungkinkan tumbuhnya kebiasaan positif \\
\hline 12 & Melaksanakan pembelajaran sesuai dengan alokasi waktu yang direncanakan \\
\hline 13 & Menggunakan media secara efektif dan efisien \\
\hline 14 & Menghasilkan pesan yang menarik \\
\hline 15 & Melibatkan siswa dalam pemanfaatan media \\
\hline 16 & Menumbuhkan partisipasi aktif siswa dalam pembelajaran \\
\hline 17 & Menunjukan sikap terbuka terhadap respon siswa \\
\hline 18 & Menumbuhkan keceriaan dan antusiame siswa dalam belajar \\
\hline 19 & Memantau kemajuan belajar selama proses \\
\hline 20 & Melakukan penilaian akhir sesuai dengan kompetensi (tujuan) \\
\hline 21 & Menggunakan bahasa lisan dan tulis secara jelas, baik dan benar \\
\hline 22 & Menyampaikan pesan dengan gaya yang sesuaI \\
\hline 23 & Melakukan refleksi atau membuat rangkuman dengan melibatkan siswa \\
\hline 24 & $\begin{array}{l}\text { Melaksanakan tindak lanjut dengan memberikan arahan, atau kegiatan, atau tugas sebagai bagian } \\
\text { remidi/pengayaan }\end{array}$ \\
\hline
\end{tabular}


menjelaskan kembali. Guru dengan bimbingan guru menyimpulkan materi pelajaran yang telah dipelajari. Menjawab pertanyaan materi pembelajaran yang telah dipelajari secara lisan.

\section{Pengamatan}

Pengamatan dilakukan untuk mengamati performansi guru Kelas V sehubungan dengan tindakan yang diberikan. Dapat dipaparkan rekapitulasi nilai kemampuan guru Kelas $\mathrm{V}$ dalam melaksanakan PBM pada siklus I Tabel 3.

Tabel 3 Nilai Observasi Kemampuan Guru Kelas V Melaksanakan PBM (Siklus I)

\begin{tabular}{clcl}
\hline No & $\begin{array}{c}\text { Nama Guru Kelas } \\
\text { V }\end{array}$ & Nilai & Kriteria \\
\hline 1 & Sunarmi Baita, S.Pd & 66 & Kurang baik \\
2 & Susilowati, A.ma.Pd & 68 & Kurang baik \\
3 & Suliyati, S.Pd & 63 & Kurang baik \\
4 & Eko Fatmawati, & 70 & Kurang baik \\
& S.Pd & & \\
5 & Rahmi Adi Atining- & 74 & Baik \\
& sih, S.Pd & & \\
6 & Yuli Astuti, A.ma.Pd & 75 & Baik \\
7 & Maria Antini, S.Pd & 80 & Baik \\
8 & Rosalia Budi S. & 84 & Sangat Baik \\
9 & Ambar D. Ang- & 68 & Kurang baik \\
& graeni, A.ma.Pd & & \\
10 & Ruth, A.Md & 73 & Baik \\
\hline \multirow{2}{*}{ Jumlah } & 721 & \\
\hline & Rata-rata & 7,21 & Baik \\
\hline
\end{tabular}

Berdasarkan pemaparan pada Tabel 3, dapat diketahui nilai rata-rata kemampuan guru dalam melaksanakan PBM pada Siklus 1 yang dicapai guru adalah 7,21 dan kualifikasi penguasaan baik. Hasil analisis menunjukkan bahwa kemampuan guru Kelas V dalam melaksanakan PBM pada Siklus 1 di Gugus Sekolah VI dan Gugus Sekolah IX di wilayah UPTD TK, SD dan PLS Dinas Pendidikan Kecamatan Lawang Kabupaten Malang, dari 10 orang guru yang diobservasi, 5 orang $(50 \%)$ memperoleh kualifikasi kurang baik, sedangkan 4 orang guru (40\%) memperoleh kualifikasi baik dan hanya 1 orang $(10 \%)$ yang memperoleh kualifikasi sangat baik.

Dari data rekapitulasi nilai observasi guru dalam melaksanakan PBM pada Siklus 1, menunjukkan bahwa proses pembelajaran yang dilaksanakan secara umum masih kurang berhasil karena persentase guru yang masih mempunyai kualifikasi kurang baik masih ada 50\% (5 orang guru). Oleh karena itu, perlu adanya program perbaikan untuk membantu para guru dengan supervisi kelompok untuk meningkatkan kemampuan guru dalam melaksanakan PBM, terutama bagi guru yang masih dalam kategori kualifikasi kurang baik dalam melaksanakan PBM, sehingga diperoleh nilai yang optimal sesuai dengan harapan peneliti.

\section{Refleksi}

Berdasarkan temuan penelitian setelah diberi tindakan I, pelaksanaan PBM oleh guru Kelas V dalam melaksanakan PBM pada Siklus II, dapat dikemukakan kurang berhasil. Oleh karena guru yang termasuk kategori kurang baik persentasenya sebesar 50\%. Peneliti berusaha mencari penyebab kekurangberhasilan dengan memperhatikan temuan-temuan di kelas berdasarkan instrument pengamatan. Diketahui bahwa masih banyak para guru yang indikatorindikator dalam melaksanakan PBM masih memperoleh nilai kurang sebagaimana disajikan tersebut di atas. Oleh karena itu, maka peneliti merasa perlu melakukan tindakan berikutnya dengan menerapkan teknik supervisi kelompok untuk meningkatkan kemampuan para guru dalam melaksanakan PBM.

\section{Siklus II \\ Perencanaan}

Dari hasil refleksi pada siklus kesatu, proses pembelajaran yang dilakukan kurang berhasil. Guru masih kesulitan dalam melaksanakan PBM. Guru yang masih mempunyai kemampuan kurang baik (nilai 3) ada 5 orang guru (50\%). Sedangkan nilai kemampuan guru dalam melaksanakan PBM pada siklus I rata-rata nilainya 7,21 . Sebelum melaksanakan proses pembelajaran, hal-hal yang perlu dipersiapkan dalam pemberian Siklus II antara lain: (1) menyusun rencana pembelajaran; (2) menyiapkan peralatan untuk mencatat hasil pengamatan selama proses pembelajaran; (3) menyusun pedoman wawancara untuk wawancara pada akhir siklus; dan (4) menyiapkan instrumen PPP. Pada Siklus II, peneliti melaksanakan supervisi kelompok terhadap para guru Kelas $\mathrm{V}$ untuk meningkatkan kemampuan dalam melaksanakan PBM.

\section{Pelaksanaan}


Prosedur pembelajaran yang dilaksanakan sesuai dengan skenario yang direncanakan. Setelah tanda bel masuk berbunyi, guru di depan kelas dan mengucapkan salam serta menyuruh ketua kelas untuk memimpin doa. Menciptakan kondisi awal pembelajaran dengan cara mengecek kehadiran guru, menciptakan kesiapan belajar guru, dan menciptakan suasana belajar yang demokrasi. Melaksanakan apersepsi dengan cara mengajukan pertanyaan-pertanyaan. Memberi komentar terhadap jawaban guru serta membangkitkan motivasi dan perhatian guru. Setelah itu menghubungkan materi pembelajaran yang telah dimiliki guru dengan materi yang akan dibahas. Memberitahukan judul materi dan tujuan pembelajaran yang akan dipelajari serta ditulis di papan tulis. Peneliti menyampaikan kegiatan belajar yang ditempuh guru. Menyajikan materi pelajaran secara klasikal dengan ceramah bervariasi. Guru menjawab pertanyaanpertanyaan yang diajukan dan bertanya tentang hal-hal yang belum dimengerti. Guru tidak terusmenerus menjelaskan tetapi selang beberapa menit selain memberi kesempatan kepada siswa untuk bertanya, kemudian dilanjutkan dengan menjelaskan kembali. Siswa dengan bimbingan guru menyimpulkan materi pelajaran yang telah dipelajari. Pada akhir tindakan siklus peneliti mengadakan wawancara dengan guru Kelas V dalam melaksanakan PBM pada Siklus II.

\section{Pengamatan}

Pengamatan dilakukan untuk mengamati performansi kemampuan guru Kelas $\mathrm{V}$ dalam melaksanakan PBM pada Siklus II. Pengamatan ini dilaksanakan dengan menggunakan Instrumen PPP. Berdasarkan pengamatan yang dilakukan pada siklus II ini. Dapat dipaparkan data nilai observasi masing-masing kemampuan guru Kelas V dalam melaksanakan PBM pada siklus II dapat dilihat pada Tabel 4.

Tabel 4 Nilai Observasi Kemampuan Guru Kelas V Melaksanakan PBM (Siklus II)

\begin{tabular}{clcl}
\hline No & Nama Guru Kelas V & Nilai & Kriteria \\
\hline 1 & Sunarmi Baita, S.Pd & 72 & Baik \\
2 & Susilowati, A.ma.Pd & 81 & $\begin{array}{l}\text { Sangat } \\
\text { baik }\end{array}$ \\
& Suliyati, S.Pd & 73 & Baik \\
4 & Eko Fatmawati, S.Pd & 80 & Baik
\end{tabular}

\begin{tabular}{|c|c|c|c|}
\hline 5 & $\begin{array}{l}\text { Rahmi Adi Atiningsih, } \\
\text { S.Pd }\end{array}$ & 83 & $\begin{array}{l}\text { Sangat } \\
\text { baik }\end{array}$ \\
\hline 6 & Yuli Astuti, A.ma.Pd & 78 & Baik \\
\hline 7 & Maria Antini, S.Pd & 86 & $\begin{array}{l}\text { Sangat } \\
\text { baik }\end{array}$ \\
\hline 8 & Rosalia Budi S. & 88 & $\begin{array}{l}\text { Sangat } \\
\text { baik }\end{array}$ \\
\hline 9 & Ambar D. Anggaraeni & 75 & Baik \\
\hline 10 & Ruth, A.Md & 84 & $\begin{array}{l}\text { Sangat } \\
\text { baik }\end{array}$ \\
\hline \multicolumn{2}{|c|}{ Jumlah } & 800 & \\
\hline \multicolumn{2}{|c|}{ Rata-rata } & 80 & Baik \\
\hline \multicolumn{4}{|c|}{$\begin{array}{l}\text { Berdasarkan Tabel } 4 \text { diketahui rata-rata } \\
\text { nilai observasi kemampuan guru kelas V dalam } \\
\text { melaksanakan PBM pada siklus II adalah } 80 \\
\text { dan termasuk dalam kualifikasi baik. Hasi } \\
\text { kemampuan guru Kelas V dalam melaksanakan } \\
\text { PBM adalah guru sebagai subyek penelitian } \\
\text { sebanyak } 10 \text { guru, guru yang dianggap sudah } \\
\text { mempunyai kemampuan sangat baik sebanyak } \\
5 \text { guru ( } 50 \% \text { ); guru yang masih belum dianggap } \\
\text { mempunyai kualifikasi yang ditingkatkan ada } \\
\text { sebanyak } 5 \text { guru ( } 50 \% \text { ). Guru yang masih perlu } \\
\text { ditingkatkan kemampuannya dalam PBM ada } \\
\text { belajar sebanyak } 5 \text { orang guru ( } 50 \% \text { ) dan perlu } \\
\text { adanya program supervisi kelompok diharapkan } \\
\text { dapat meningkatkan kemampuan guru Kelas } \\
\text { V, khususnya yang masih perlu ditingkatkan } \\
\text { kualifikasinya. }\end{array}$} \\
\hline
\end{tabular}

\section{Refleksi}

Berdasarkan temuan penelitian pada Siklus II, rata-rata nilai kemampuan guru dalam melaksanakan PBM yang diperoleh guru mengalami peningkatan sebesar 7,90 dari 72,10 pada siklus Imeningkatkan menjadi 80 pada siklus II. Meningkatkannya kemampuan guru dalam melaksanakan PBM diduga merupakan hasil dari perubahan karena adanya tindakan II melalui supervisi kelompok. Meskipun ada peningkatan kemampuan guru dalam melaksanakan PBM, tindakan II yang dilaksanakan perlu untuk ditingkatkan lagi dengan supervisi kelompok terhadap para guru.

Masih banyak para guru yang indikatorindikator dalam pelaksanaan PBM masih memperoleh nilai kurang sebagaimana disajikan tersebut diatas, walaupun apabila dibandingkan dengan siklus I sudah relatif berkurang, baik jumlah indikatornya dalam pelaksanaan PBM maupun jumlah guru pada setiap indikator juga 
berkurang. Oleh karena itu, maka peneliti merasa perlu melakukan tindakan berikutnya dengan menerapkan teknik supervisi kelompok untuk meningkatkan kemampuan para guru dalam melaksanakan PBM dengan tetap memperhatikan indikator-indikator yang masih memperoleh nilai kurang baik (nilai 3).

\section{Siklus III}

\section{Perencanaan}

Dari hasil refleksi pada siklus kedua, tindakan yang dilakukan kurang berhasil meskipun ada peningkatan kemampuan guru dalam melaksanakan PBM. Ada 5 guru yang belum memenuhi kualifikasi sangat baik. Sebelum melaksanakan tindakan berikutnya, hal-hal yang perlu dipersiapkan dalam pemberian tindakan III adalah: (1) menyusun rencana pembelajaran; (2) mencatat hasil pengamatan selama proses pembelajaran; dan (3) menyusun pedoman wawancara untuk wawancara pada akhir siklus.

Pada siklus III, peneliti melakukan pendekatan dengan supervisi kelompok terhadap para guru, terutama yang indikator kemampuan dalam pelaksanaan PBM masih memperoleh nilai kurang baik (nilai 3). Penekanan supervisi kelompok adalah para peningkatan kemampuan Guru Kelas V dalam melaksanakan PBM.

\section{Pelaksanaan}

Prosedur pembelajaran yang dilaksanakan sesuai dengan skenario yang direncanakan. Setelah tanda bel masuk berbunyi, guru di depan kelas dan mengucapkan salam serta menyuruh ketua kelas untuk memimpin doa. Menciptakan kondisi awal pembelajaran dengan cara mengecek kehadiran guru, menciptakan kesiapan belajar guru, dan menciptakan suasana belajar yang demokrasi. Melaksanakan apersepsi dengan cara mengajukan pertanyaan-pertanyaan. Memberi komentar terhadap jawaban guru serta membangkitkan motivasi dan perhatian guru.

Setelah itu menghubungkan materi pembelajaran yang telah dimiliki guru dengan materi yang akan dibahas. Memberitahukan judul materi dan tujuan pembelajaran yang akan dipelajari serta ditulis di papan tulis. Peneliti menyampaikan kegiatan belajar yang ditempuh guru. Menyajikan materi pelajaran secara klasikal dengan ceramah bervariasi. Guru menjawab pertanyaan-pertanyaan yang diajukan dan bertanya tentang hal-hal yang belum dimengerti. Guru tidak terus-menerus menjelaskan tetapi selang beberapa menit selain memberi kesempatan kepada guru untuk bertanya, kemudian dilanjutkan dengan menjelaskan kembali. Guru dengan bimbingan guru menyimpulkan materi pelajaran yang telah dipelajari. Menjawab pertanyaan materi pembelajaran yang telah dipelajari secara lisan. Pada akhir tindakan siklus peneliti mengadakan wawancara dengan guru untuk mencari informasi tentang kesulitan yang dihadapi dan komentar terhadap proses belajar mengajar yang diterapkan guru di kelas.

\section{Pengamatan}

Pengamatan dilakukan untuk mengamati performansi kemampuan guru Kelas $\mathrm{V}$ dalam melaksanakan PBM pada Siklus III. Pengamatan ini dilaksanakan dengan menggunakan Instrumen Penilaian Pelaksanaan Pembelajaran (IPPP). Dapat dipaparkan data nilai observasi masingmasing kemampuan guru pada Tabel 5.

Tabel 5 Nilai Observasi Kemampuan Guru Kelas V Melaksanakan PBM (Siklus III)

\begin{tabular}{clcl}
\hline No & \multicolumn{1}{c}{$\begin{array}{c}\text { Nama dan NIP } \\
\text { Guru Kelas V }\end{array}$} & Nilai & Kriteria \\
\hline 1 & Sunarmi Baita, S.Pd & 85 & Sangat baik \\
2 & Susilowati, A.ma.Pd & 88 & Sangat baik \\
3 & Suliyati, S.Pd & 83 & Sangat baik \\
4 & Eko Fatmawati, S.Pd & 84 & Sangat baik \\
5 & Rahmi Adi & 87 & Sangat baik \\
& Atiningsih, S.Pd & & \\
6 & Yuli Astuti, A.ma.Pd & 83 & Sangat baik \\
7 & Maria Antini, S.Pd & 93 & Sangat baik \\
8 & Rosalia Budi S. & 92 & Sangat baik \\
9 & Ambar D. Anggareni, & 84 & Sangat baik \\
& A.ma.Pd & & \\
10 & Ruth, A.Md & 86 & Sangat baik \\
\hline Jumlah & 865 & \\
\hline Rata-rata & 86,50 & Sangat baik \\
\hline
\end{tabular}

Berdasarkan Tabel 5 dapat diketahui bahwa nilai rata-rata Kemampuan Guru Kelas V dalam Melaksanakan PBM Tes pada Siklus III yang dicapai guru adalah 86,50 dengan kualifikasi sangat baik. Berdasarkan data dari Tabel 8 , siklus III menunjukkan bahwa kemampuan guru dalam melaksanakan PBM pada Siklus III seluruhnya (10 orang guru) memperoleh kualifikasi sangat 
baik (nilai masing-masing di atas 80 ).

\section{Refleksi}

Data tentang kemampuan guru dalam melaksanakan PBM pada Siklus III yang dicapai guru adalah 86,50 dengan kualifikasi setelah pemberian tindakan III, kemudian dianalisis untuk memperoleh temuan-temuan. Berdasarkan temuan penelitian setelah diberi tindakan III, hasil peningkatan kemampua guru dalam melaksanakan PBM mengalami peningkatan secara signifikan, karena seluruh guru dapat dikategorikan berhasil dengan kualifikasi sangat baik (nilai yang diperoleh masing-masing guru di atas 80).

Peningkatan kemampuan guru dalam melaksanakan PBM tampak dari perubahan nilai rata-rata kemampuan guru pada siklus II, sebesar 80 dan pada siklus III nilai rata-rata kemampuan guru adalah sebesar 86,50. Dengan demikian terjadi peningkatan dari nilai rata-rata kemampuan guru dalam melaksanakan PBM sebesar 6,50. Peningkatan nilai kemampuan guru dalam melaksanakan PBM dari Siklus I, Siklus II, dan Siklus III dapat dilihat pada Tabel 6.

Berdasarkan Tabel 6 diketahui rata-rata nilai kemampuan guru pada dasarnya ada peningkatan kemampuan guru dalam melaksanakan PBM dengan adanya tindakan melalui supervisi kelompok. Kondisi yang mempengaruhi prestasi belajarnya. Hal ini dapat dilihat dari nilai ratarata dari Siklus I ke Siklus II, ada peningkatan 7,90. Sedangkan dari Siklus I ke Siklus III ada peningkatan sebesar 14,40. Dengan demikian dapat dikemukakan bahwa tindakan terhadap para guru dengan supervisi kelompok memperoleh peningkatan hasil yang signifikan. Siklus III selain ada peningkatan nilai rata-rata kemampuan guru dalam melaksanakan PBM, di samping itu pada Siklus III, tidak ada indikatorindikator yang memperoleh nilai kurang baik, semua indikator dalam melaksanakan PBM pada semua guru memperoleh nilai baik dan sangat baik.

\section{PEMBAHASAN}

Tugas guru utamanya adalah melaksanakan proses belajar mengajar (PBM). Oleh karena itu, seorang guru harus menguasai beberapa kompetensi proses belajar, antara lain secara garis besar yang termasuk dalam cakupan PBM ini adalah: (1) prapembelajaran; (2) kegiatan inti pembelajaran, yang meliputi penguasaan materi pelajaran, pendekatan/strategi pembelajaran, pemanfaatan sumber belajar, media pembelajaran, pembelajaran yang memicu dan memelihara keterlibatan siswa, penilaian proses dan hasil belajar, dan penggunaan bahasa; dan (3) penutup. Tindakan pada Siklus I, II dan III ini dilakukan oleh Pengawas Sekolah selaku supervisor yang mempunyai tanggung jawab untuk meningkatkan mutu tenaga kependidikan, baik kepala sekolah maupun guru yang ada dalam wilayah binaannya. Petunjuk Pelaksanaan Supervisi Pendidikan di Sekolah menjelaskan supervisi ialah bantuan yang diberikan kepada seluruh staf sekolah untuk mengembangkan situasi belajar mengajar yang lebih baik (Depdikbud, 1994:2).

Membimbing guru adalah tugas dari seorang supervisor (kepala sekolah / pengawas sekolah), yaitu membimbing guru dalam menyusun silabus tiap matapelajaran dalam rumpun matapelajaran yang relevan di sekolah dasar berlandaskan standar isi, standar kompetensi dan kompetensi dasar, dan prinsip-prinsip pengembangan kurikulum, membimbing guru dalam memilih dan menggunakan strategi, metode, teknik pembelajaran, bimbingan yang dapat mengembangkan berbagai potensi siswa melalui mata-mata pelajaran dalam rumpun mata pelajaran yang relevan di sekolah dasar, dan membimbing guru dalam menyusun rencana pelaksanaan pembelajaran (RPP) untuk tiap mata pelajaran. Teknik supervisi kelompok adalah satu cara melaksanakan program supervisi yang ditujukan pada dua orang atau lebih. Guru yang akan disupervisi berdasarkan hasil analisis

Tabel 6 Rekapitulasi Rerata Nilai Kemampuan Guru Kelas V Melaksanakan PBM

\begin{tabular}{clccc}
\hline No & Siklus ke & $\begin{array}{c}\text { Rata-rata Nilai Kemampuan Guru } \\
\text { Kelas V Melaksanakan PBM }\end{array}$ & Kualifikasi & $\begin{array}{c}\text { Peningkatan Nilai } \\
\text { Rata-rata }\end{array}$ \\
\hline 1 & Siklus I & 72,10 & Baik & - \\
2 & Siklus II & 80,00 & Baik & 7,90 \\
3 & Siklus III & 86,50 & Sangat Baik & 14,40 \\
\hline
\end{tabular}


kebutuhan dan analisis kemampuan kinerja guru, kemudian dikelompokan berdasarkan kebutuhan guru.

Kemudian guru diberikan layanan supervisi sesuai dengan permasalahan atau kebutuhan yang diperlukan (Kemendiknas, 2011:20). Perlu dikemukakan bahwa pembinaan dan pembimbingan oleh pengawas sekolah terhadap kemampuan guru Kelas V Gugus VI dan IX UPTD TK, SD, dan PLS Dinas Pendidikan Kecamatan Lawang Kabupaten Malang dalam melaksanakan PBM melalui supervisi kelompok cukup efektif. Hal ini terbukti bahwa dari semula rata-rata mempunyai kualifikasi kurang baik menjadi rata-rata kualifikasinya sangat baik. Hal ini menunjukkan bahwa kewajiban seorang supervisor (pengawas sekolah) dalam memberikan pembinaan terhadap para guru telah dilaksanakan dengan baik.

\section{SIMPULAN DAN SARAN}

Berdasarkan hasil penelitian dan pembahasan tersebut di muka, maka dapat disimpulkan: (1) tingkat kemampuan melaksanakan PBM para guru Kelas V Gugus Sekolah VI dan Gugus Sekolah IX di Wilayah UPTD TK, SD, dan PLS Dinas Pendidikan Kecamatan Lawang Kabupaten Malang meningkat secara sinifikan setelah dilakukan penelitian tindakan sekolah pada Siklus I, Siklus II dan Siklus III; (2) supervisi kelompok yang dilaksanakan oleh Pengawas Sekolah dalam tindakan sekolah dalam Siklus I, II, dan III dapat meningkatkan kemampuan guru Kelas V dalam melaksanakan PBM bagi para guru yang berada dalam kelompok Gugus Sekolah VI dan Gugus Sekolah IX di Wilayah UPTD TK, SD dan PLS Dinas Pendidikan Kecamatan Lawang Kabupaten Malang; dan (3) peningkatan kemampuan guru Kelas V Gugus VI dan IX UPTD TK, SD, dan PLS Kecamatan Lawang Kabupaten Malang dalam melaksanakan PBM dapat dilihat dari rekapitulasi skor nilai rata-rata pada Siklus I memperoleh nilai 72,10 (kualifikasi baik), Siklus II memperoleh skor nilai rata-rata 80 (kualifikasi baik), dan pada Siklus II memperoleh skor nilai rata-rata 86,50 (kualifikasi sangat baik).

Berdasarkan simpulan penelitian, dikemukakan saran bagi guru adalah hasil penelitian tindakan sekolah di atas telah menunjukkan bahwa melalui supervisi kelompok oleh Pengawas Sekolah, kemampuan guru Kelas V Gugus VI dan IX UPTD TK, SD, dan PLS Kecamatan Lawang Kabupaten Malang dalam melaksanakan PBM dapat ditingkatkan. Oleh karena itu, disarankan kepada guru untuk terus meningkatkan kemampuannya dengan bimbingan oleh Kepala Sekolah dan/atau Pengawas Sekolah maupun secara mandiri dalam melaksanakan PBM di kelas sebagai konsekuensi tugas dan tanggung jawabnya mengemban jabatan sebagai tenaga kependidikan. Bagi Kepala Sekolah adalah mengingat pentingnya tugas guru dalam melaksanakan PBM di kelas, terutama dalam kaitannya meningkatkan mutu pendidikan, maka disarankan bagi Kepala Sekolah untuk menindaklanjuti program pembinaan dan pembimbingan yang telah dilaksanakan oleh Pengawas Sekolah dalam rangka meningkatkan kemampuan guru dalam melaksanakan PBM.

\section{DAFTAR RUJUKAN}

Cooper, J. M. 1990. Classroom Teaching Skill. Lexington, Massachusetts Toronto: D.C. Heath and Company.

Depdikbud. 1994. Petunjuk Pelaksanaan Supervisi Pendidikan di Sekolah. Jakarta: Direktorat Pendidikan Menengah Umum, Direktorat Jenderal Pendidikan Dasar dan Menengah, Departemen Pendidikan dan Kebudayaan.

Fathurrohman, P. dan Suryana, A. A. 2011. Supervisi Pendidikan dalam Pengembangan Proses Pengajaran. Bandung: PT Refika Aditama.

Kemendiknas. 2011. Supervisi Akademik: Suplemen Materi Pelatihan Penguatan Kemampuan Kepala Sekolah. Jakarta: Pusat Pengembangan Tenaga Kependidikan, Badan Pengembangan Sumber Daya Manusia Pendidikan dan Penjaminan Mutu Pendidikan, Kementerian Pendidikan Nasional.

Lestari, T. 2008. Merencanakan dan Melaksanakan Penelitian Tindakan Sekolah. Makalah disampaikan pada Kegiatan Pembekalan Pembimbing Penelitian Tindakan Sekolah Tanggal 16 s.d. 17 Mei 2000 di Hotel Poencer, Cisarua Bogor.

Marno, dan Idris. 2008. Belajar dan Pembelajaran. Bandung: Rineka Cipta.

Peraturan Menteri Pendidikan Nasional Nomor 12 Tahun 2007 tentang Standar Kompetensi Pengawas Sekolah/Madrasah, (Online), (http:// www.depdiknas.go.id), diakses 21 Juli 2009.

Peraturan Pemerintah Nomor 10 tahun 2009 Sertifikasi Guru dalam Jabatan, (Online), (http:// www.depdiknas.go.id), diakses 25 Juli 2009. 
Peraturan Pemerintah Nomor 19 tahun 2005 Standar Nasional Pendidikan, (Online), (http://www. depdiknas.go.id), diakses 2 Juli 2006.

Sanjaya, W. 2008. Strategi Pembelajaran: Berorientasi Standar Proses Pendidikan. Jakarta: Kencana Prenada Media Group.

Suhardjono. 2008. Penelitian Tindakan Sekolah sebagai Kegiatan Pengembangan Profesi bagi Pengawas Sekolah. Makalah Pendukung Sajian Lisan pada Workshop Penulisan Karya Ilmiah (KTI) untuk Kenaikan Golongan bagi Pengawas, Dinas Pendidikan Pemerintah Kota Depok, Depok, 28 Juli.
Suparno, P. 2008. Action Research: Riset Tindakan untuk Pendidik. Jakarta: PT Gramedia Widiasarana Indonesia.

Undang-undang Nomor 14 Tahun 2005 tentang Guru dan Dosen, (Online), (http://www.depdiknas. go.id), diakses 2 Juli 2006.

Undang-undang Nomor 20 Tahun 2003 tentang Sistem Pendidikan Nasional, (Online), (http:// www.depdiknas.go.id), diakses 2 Juli 2006. 